\title{
Pohřby kultury se šňůrovou keramikou z Prahy-Ruzyně
}

\author{
Burials of the Corded Ware Culture from Prague-Ruzyně
}

\author{
Katarína Petriščáková - Miroslava Šmolíková
}

\begin{abstract}
Abstrakt
V průběhu záchranného archeologického výzkumu Muzea hlavního města Prahy v roce 1999 v Praze-Ruzyni byl prozkoumán jeden hrob kultury se šňůrovou keramikou. V hrobu ležely pozůstatky dvou jedinců: dospělého muže a dítěte. Hrobová výbava pozůstávala pouze z keramických nálezů a blíže neurčených zvírecích kostí. Analýza keramického inventáře zařadila hrob do III. nálezové skupiny. Analýza AMS dospělého jedince určila stáří hrobu v rozmezí let $3981 \pm 22$ BP.
\end{abstract}

\begin{abstract}
One grave of Corded Ware Culture was excavated in the course of the rescue excavation by the City of Prague Museum in Prague-Ruzyně in 1999. In the isolated grave lay two burials: adult man and child inhumations. The grave also contained pottery and unspecified animal bones. Analysis of assemblage put this grave in the find-group III. AMS data of adult human remains confirm the years between $3981 \pm 22 \mathrm{BP}$.
\end{abstract}

Klíčová slova: pohřby - kultura se šňůrovou keramikou - keramika - radiokarbonové datování

Key words: burials - Corded Ware Culture - pottery - Radiocarbon analysis

DOI: $10.14712 / 25707213.2019 .1$

\section{Úvod a lokalizace}

V průběhu května až srpna roku 1999 realizovalo Muzeum hlavního města Prahy záchranný archeologický výzkum v souvislosti s výstavbou komunikace stavba 517 Řepy-Ruzyně, která je součástí Pražského okruhu v Praze-Ruzyni (Baštová - Šmolíková 1999).

Lokalita je situovaná v západní části Prahy, v jižní části k. ú. Ruzyně na parcele č. 1226/1, v trati Za Poustkami, východně od areálu bývalých Uhelných skladů při ulici Na Hůrce a severně od Karlovarské ulice (obr. 1). V současnosti je střed zkoumané plochy vymezen souřadnicemi: $50^{\circ} 04^{\prime} 46.4^{\prime \prime} \mathrm{N}$, $14^{\circ} 17^{\prime} 33.9^{\prime \prime} \mathrm{E}$.

Poloha se rozkládala na mírném svahu obráceném k jihovýchodu v nadmořské výšce 328-334 m, východně od bezejmenného levobřežního přítoku Litovického potoka, severně od toku Litovického potoka a západně od retenční nádrže Jiviny.

\section{Okolnosti výzkumu a popis terénní situace}

Prostor stavby budoucí komunikace byl rozdělen na tři velké plochy, menší sondážní rýhy a výkop pro přeložku kabelu. Pouze na ploše I a II proběhl destruktivní záchranný výzkum. Plocha III skrytá pouze pro potřeby deponie vytěžené hlíny, byla po povrchovém zaměření objektů opět zahrnutá hlínou, aby nedošlo k narušení a poškození archeologických situací těžkou mechanizací. Výzkum prvních dvou ploch odhalil polykulturní lokalitu se sídlištními i pohřebními komponenty z časového úseku od neolitu až po mladší dobu bronzovou. Pravěké situace zjištěny v liniových rýhách a výkopech podél hlavních ploch byly z časových důvodů pouze vzorkovány. Z lokality byl zatím publikován hromadný nález broušené industrie kultury s vypíchanou keramikou (Baštová - Šmolíková - Zavřel 2011, 67-78) a pohře- 

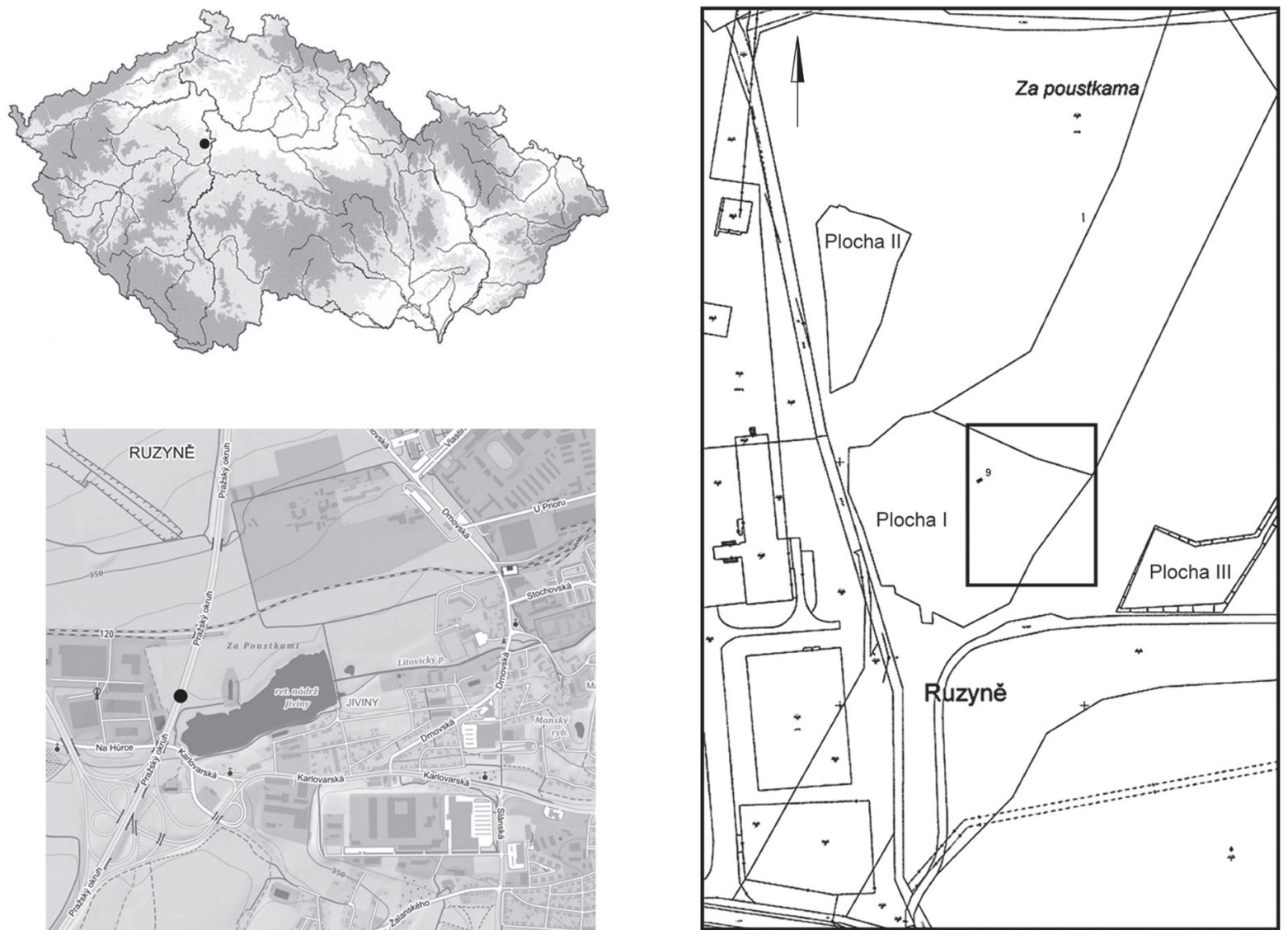

Obr. 1. Lokalizace výzkumu Praha-Ruzyně „Za Poustkami“ a poloha hrobu 9 na Ploše I. - Fig. 1. Location of the site Prague-Ruzyně "Za Poustkami” and position of the Grave 9 in the Area I.

biště starší únětické kultury (Petriščáková - Pavúk a kol. 2015, 24-53, 293-294). Hrob kultury se šňůrovou keramikou ležel v SV části Plochy I mezi hroby únětické kultury. Intenzívní zemědělská činnost a provedená mechanická skrývka ornice o mocnosti asi $60 \mathrm{~cm}$ značně narušily téměř všechny vrchní části mělce zahloubených pravěkých objektů včetně zde publikovaného hrobu. $\mathrm{Z}$ tohoto důvodu byl zaznamenaný konečný stav archeologických objektů značně neuspokojivý.

\section{Popis hrobu a nálezů (obr. 2-5) ${ }^{\mathbf{1}}$}

\section{Hrob 9}

Jáma téměř obdélného půdorysu s mírně svažujícími se stěnami a rovným dnem, zahloubená do okrově

1 Zkratky: d - délka, š - šířka, hl. hloubka, OŠ - otisk šňůry, $\mathrm{T}$ - tělo nádoby, $\mathrm{H}$ - hrdlo, O - okraj, D - dno, zach. zachovaná, v - výška, OAS MMP - Oddělení archeologických sbírek Muzea hlavního města Prahy, Inv. č. - inventární číslo. Rozměry nálezů jsou udávané v milimetrech. Ćísla nálezů v katalogu odpovídají číslům v obrazové dokumentaci. hlinitého podloží. Rozměry: max. d - $224 \mathrm{~cm}$, max. š $-165 \mathrm{~cm}$, hl. $32 \mathrm{~cm}$. Výplň: kompaktní vrstva tmavě hnědé hlíny s občasnou příměsí drobných uhlíků. Na dně spočívaly pozůstatky dvou jedinců. Téměř uprostřed jámy ležel na pravém boku dospělý jedinec $(\alpha)$ ve směru ZSZ (hlava) - VJV (nohy). V jižní polovině hrobové jámy byly nalezeny pozůstatky dítěte $(\beta)$ v poloze na pravém boku ve shodné ZSZ-VJV orientaci s dospělým jedincem. V JZ polovině hrobové jámy, pravděpodobně nedaleko hlavy nedospělého jedince ležel pohár (1). V prostoru mezi chodidly a zadní části dospělého jedince ležela amfora (2). Zbylé keramické zlomky a zvířecí kosti byly roztroušené v prostoru vrchních partií obou jedinců (3-12). Antropologických rozborem bylo zjištěno, že kostra došlého jedince patří muži ve věku maturus (40-60 let) a menší kostra dítěti ve věku infans II, tj. asi 10 let (viz Př́loha, Dobisíková - Velemínský 2015). Nálezy jsou uloženy v OAS MMP pod př́růstkovým číslem A 109/2002.

\section{Nálezy:}

1. Hrnek s ouškem, $O$ mírně vyhnutý, D nezachované. Povrch zdrsněný, skvrnitý, setřený. Barva 

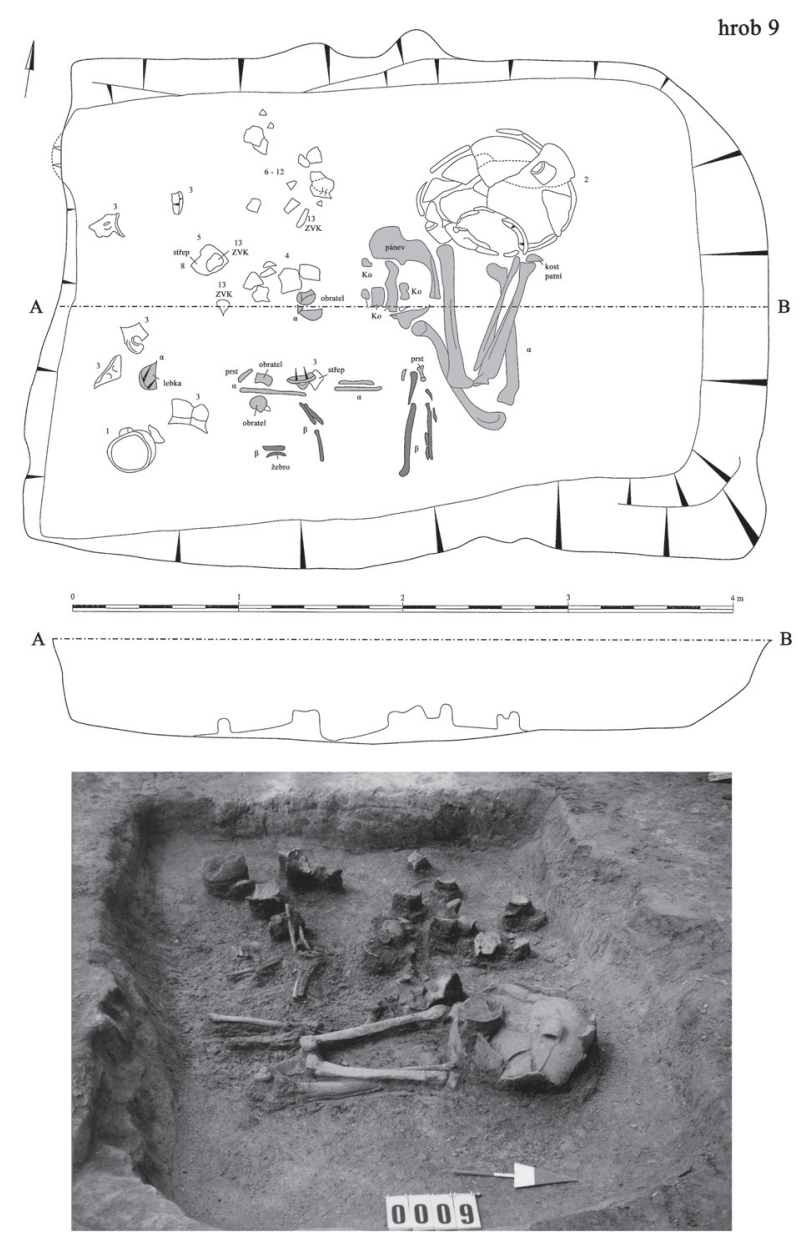

Obr. 2. Praha-Ruzyně. Hrob 9: $\alpha$ - dospělý jedinec, $\beta$ - dítě. Foto M. Šmolíková, pohled od V. Grafická úprava M. Kafka. - Fig. 2. Prague-Ruzyně. Grave 9: $\alpha$ - adult, $\beta$ - child. Photo view from the East.

cihlová. Částečně slepený, doplněný a volné zlomky. Rozměry: zach. v - 130, ø O - 105. Inv. č. A 274195 (obr. 3: 1).

2. Amfora se dvěma U na max. výduti, na plecích zdobená dvěma hladkými vertikálními lištami a jednou horizontální hladkou lištou na $\mathrm{H}$ a po obvodu max. výdutě. Povrch hladký, skvrnitý. Barva hnědá, ve spodní části černá. Slepená, částečně doplněná. Rozměry: v - 363, ø O - 155, ø D - 95. Inv. č. A 274200 (obr. 3: 2).

3. Fragment amfory se dvěma U na max. výduti, na rozhraní $\mathrm{H}$ a plecí pravidelně rozmístěny původně 4 subkutánní ouška, dochovány pouze 3 . Povrch hlazený. Barva černá. Částečně slepená a volné zlomky. Rozměry: zach. v - 220, ø D - 70. Inv. č. A 274197 (obr. 4: 3).

4. Fragment amfory s jedním dochovaným ouškem, zdobená po obvodu 3× OŠ a trojúhelníky. Povrch hladký, skvrnitý. Barva hnědá. Částečně sle-

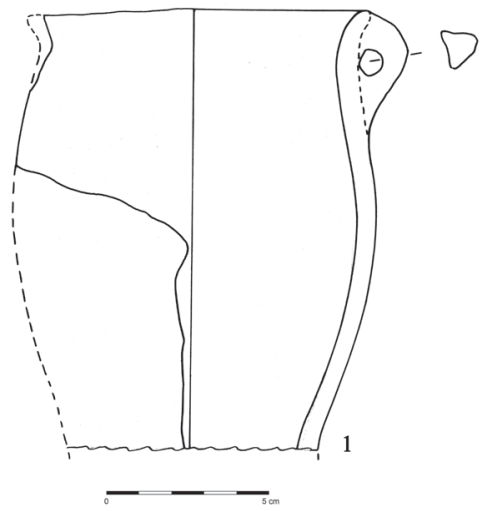

hrob 9

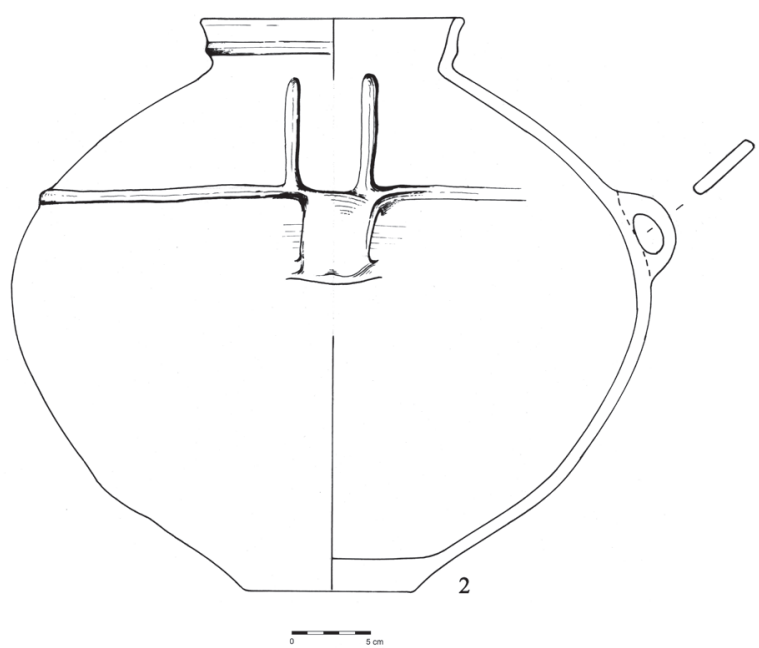

Obr. 3. Praha-Ruzyně. Hrob 9. Keramika. Kresby M. Fábiková. Grafická úprava M. Kafka. - Fig. 3. Prague-Ruzyně. Grave 9. Pottery.

pená, doplněná. Rozměry: ø D - 60. Inv. č. A 274198 (obr. 5: 4).

5. O rovný, nezdobený. Inv. č. A 274186 (obr. 5: 5).

6. O zdobený $2 \times$ OŠ. Inv. č. A 274187 (obr. 5: 6).

7. T zdobené zbytkem OŠ. Inv. č. A 274188 (obr. 5:7).

8. T zdobené 3× OŠ. Inv. č. A 274189 (obr. 5: 8).

9. T zdobené zbytkem hladké lišty. Inv. č. A 274190 (obr. 5: 9).

10. T zdobené 4× OŠ. Inv. č. A 274191 (obr. 5: 10). 11.-12. 2× $\mathrm{T}$ nezdobená $\mathrm{z}$ různých nádob. Inv. č. A 274 192. Nekreslené.

13. Zlomky blíže neurčených zviřecích kostí.

Datování: radiouhlíková data CRL-17_484, 3981 $\pm 22 \mathrm{BP}^{2}$

2 Za provedenou analýzu autorky děkují Ing. I. Světlíkovi, Ph.D. z CRL - Radiouhlíkové laboratoře Ústavu jaderné fyziky AV ČR, v. v. i., Na Truhlářce 39/64, 18086 Praha 8. 

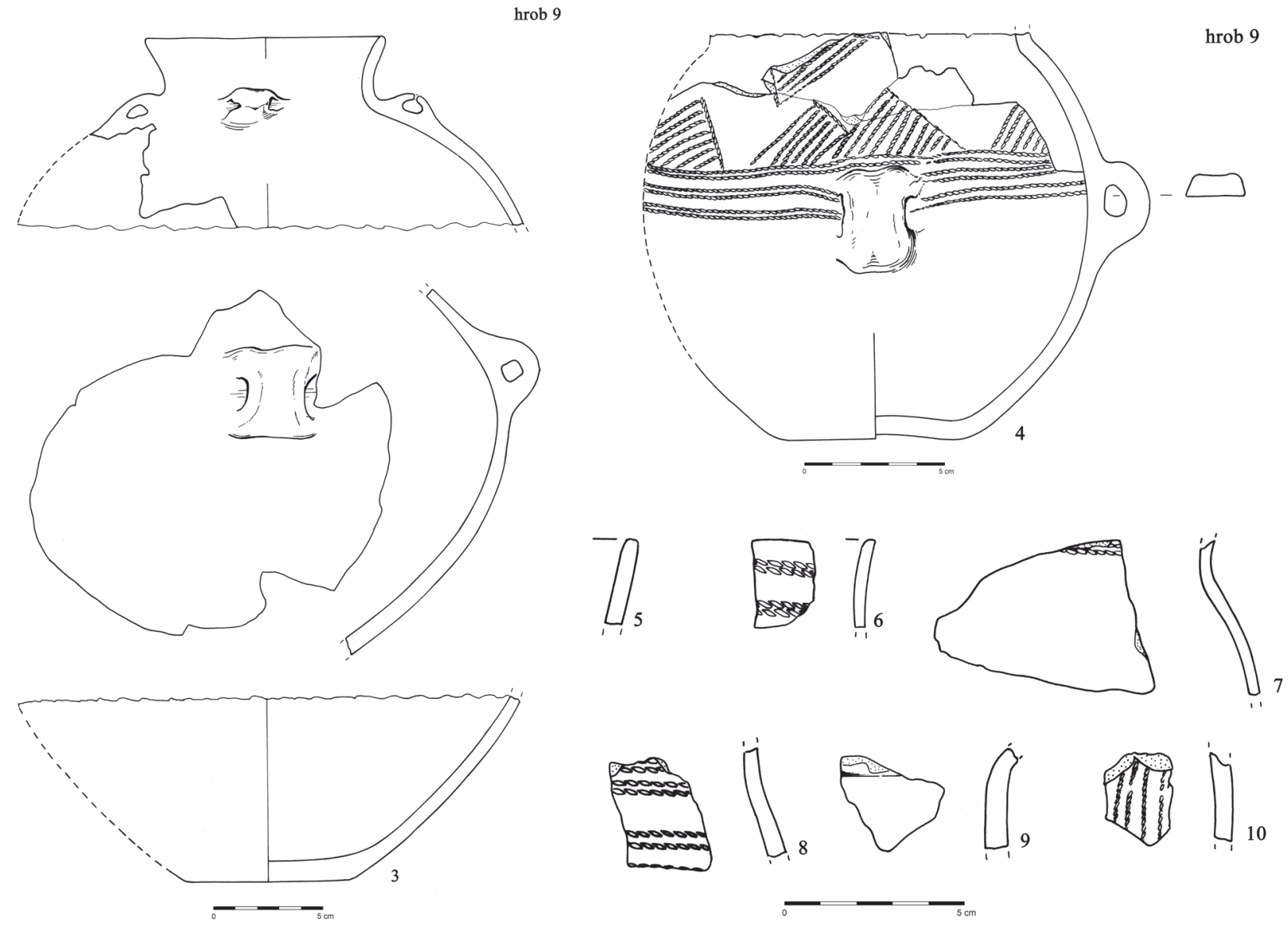

Obr. 4. Praha-Ruzyně. Hrob 9. Keramika. Kresby M. Fábiková. Grafická úprava M. Kafka. - Fig. 4. Prague-Ruzyně. Grave 9. Pottery.

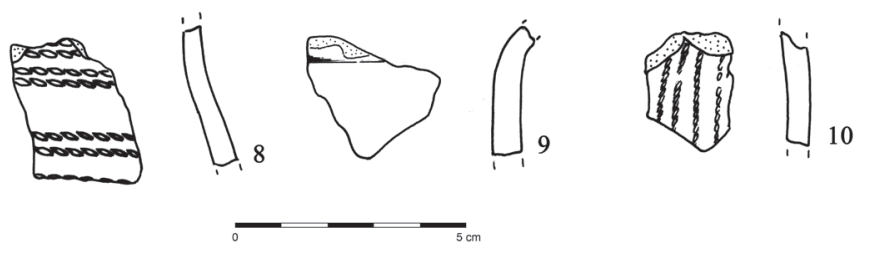

Obr. 5. Praha-Ruzyně. Hrob 9. Keramika. Kresby M. Fábiková. Grafická úprava M. Kafka. - Fig. 5. Prague-Ruzyně. Grave 9. Pottery.

\section{Vyhodnocení nálezů a nálezové situace}

Na lokalitě Praha-Ruzyně v poloze „Za Poustkami“ byl mezi hroby únětické kultury identifikován jeden hrob (č. 9) kultury se šňůrovou keramikou (obr. 2). $\mathrm{V}$ jámě podélného půdorysu ležely pozůstatky dvou jedinců orientované shodným směrem ZSZ (hlava) - VJV (nohy). Velikost hrobové jámy odpovídá již známým zjištěním, že rozměry jsou přizpůsobeny počtu pohřbených osob. V našem př́padě je velikost hrobu uzpůsobená pro pohřeb dvou osob. Jakékoliv další pozorování je limitováno stavem odkryvu, kdy již v primární fázi došlo $\mathrm{k}$ narušení povrchu hrobové jámy skrývkou. Poloha pohřbeného dospělého koreluje s antropologickým zjištěním, které určilo, že ostatky patřri jedinci mužského pohlaví. V př́ípadě nedospělého jedince jsme $\mathrm{z}$ patřičných důvodů ochuzeni o určení pohlaví a $\mathrm{v}$ tomto př́ípadě nelze spoléhat ani na uložení v hrobové jámě, kdy je jeho orientace shodná s „mužskou“. Př́ípady současných pohřbů do jedné hrobové jámy v kultuře se šňůrovou keramikou jsou jevem poměrně vzácným a nejčastěji se vykytují ve složení dospělá žena (pravděpodobně matka) a dítě, kdy je dítě (většinou bez antropologicky určeného pohlaví) uložené ve shodném směru jako dospělá. Při pohřbech dvou dospělých jedinců rozdílného pohlaví je registrována antipodická poloha zemřelých. U vícečetných pohřbů tří a více jedinců v jedné hrobové jámě není nezvyklé „vybočení" z jinak striktně zavedených „genderových" stereotypů, kdy jsou všichni zemřelí orientování jedním shodným směrem ( $c f$. Turek $2001,4-5$; Neustupný 2008, 142). Polohu rukou nebylo možné určit ani $v$ jednom př́padě. Pouze u dospělého jedince můžeme uvažovat o středním skrčení a přitažení dolních končetin.

Hrobové nálezy pozůstávaly pouze ze zvírecích kostí a čtyř keramických nádob, na jejichž základě lze hrob bez problémů zařadit do kultury se šňůrovou keramikou. Většina nádob je nekompletní, možno ale předpokládat, že přibližně první dvě nádoby (1-2) byly ve formě prídavků vložené kom- 
pletně celé. Hrnek s ouškem (obr. 3: 1), který ležel za temenem hlavy nedospělého jedince možno definovat spíše jako vejčitý hrnek typu P, blíže k typu P2 (podle Buchvaldek 1986, 91, 105). Nádoba z hrobu v Ruzyni disponuje více protáhlým a méně vejčitým tvarem. Podobné nálezy pochází např̀. z pohřebiště ve Vliněvsi (Dobeš - Limburský a kol. 2013, 120). Výskyt těchto hrnků je spíše vázán na ženské hroby III. nálezové skupiny. Nejvíce zastoupeným inventářem jsou pak amfory. Amfora s plastickými liniemi na plecích a neúplnou vodorovnou lištou na max. výduti (obr. 3: 2) je podobná typu A 18 (Buchvaldek 1986 , obr. 44; 88). Ležela v prostoru mezi chodidly a zády dospělého jedince př́mo na dně hrobové jámy. Další amforu se čtyřmi subkutánními oušky bez další patrné výzdoby (obr. 4: 3) nelze přesně typologicky zařadit, ale nejvíce se přibližuje typu A 22 (týz 1986, obr. 44; 88). Vzhledem k její fragmentárnosti a umístění v horních partiích pohřbených, pravděpodobně někde kolem hlavy dospělého, lze uvažovat o druhotném přemístění prídavku. Torzo poslední amfory leželo pravděpodobně za zády pohřbeného dospělého. Výzdobné prvky v podobě horizontálních otisků šñury a stojících trojúhelníků (obr. 5: 4) se nejvíce blíží typům A 20 až A21 a (týž 1986, obr. 44; 88). Fragmenty ostatních nádob zdobené otiskem šňůry $(6-10)$ jsou bezpochyby pozůstatky nádob téhož období (obr. 5: 5-10). Diskutabilní je př́tomnost vejčitého hrnku v podobě př́́davku $\mathrm{v}$ hrobu s mužským jedincem (obr. 2). Tyto nádoby se vyskytují většinou v páru po dvou v ženských hrobech (Buchvaldek - Popelka 1994, 32). Vzhledem $\mathrm{k}$ tomu, že neznáme pohlaví druhého pohřbeného jedince, lze proto uvažovat, že šlo spíše o nedospělou osobu ženského pohlaví. Zvířecí kosti nalezené ve velmi fragmentárním stavu mezi keramickými př́davky nelze blíže specifikovat, a proto není zcela zřejmé, zda se jednalo o cílený př́davek, nebo pouze o nechtěnou př́měs.

Provedená AMS analýza kosterních pozůstatků dospělého jedince určila stáří hrobu v rozmezí let $3981 \pm 22$ BP. ${ }^{3}$ Naměřená data plně spadají do analyzovaného období (naposledy souhrnně Dobeš - Limburskýa kol. 2013, 103-108).

\section{Závěr}

V roce 1999 provádělo Muzeum hlavního města Prahy záchranný archeologický výzkum v souvislosti s výstavbou Pražského okruhu v úseku Praha-Ruzyně. Na polykulturní lokalitě „Za Poustkami“

3 Uvedená data po kalibraci ukazují 2561-2492 BC (pravděpodobnost $68,2 \%$, tedy $1 \delta$ ), resp. 2570-2501 BC (pravděpodobnost $95,4 \%$, tedy 28 ). byl mezi hroby únětické kultury odkrytý jeden hrob kultury se šňurovou keramikou. $V$ jámě podélného půdorysu leželi dva jedinci shodně orientovaným směrem ZSZ-VJV. Dospělý muž ležel na pravém boku se středně skrčenými nohami, horní polovina těla se nedochovala. Tomuto jedinci můžeme jednoznačně přisoudit př́davek $\mathrm{v}$ podobě amfory typu A 18, která se nacházela v prostoru mezi jeho zády a chodidly. Dalším pohřbeným byl nedospělý jedinec neurčeného pohlaví, který ležel po pravé straně dospělého zemřelého. Stupeň skrčení a polohu končetin nebylo možné určit. Př́davek v podobě vejčitého hrnku ležel za temenem hlavy dítěte. V tomto případě jsme ochuzeni o antropologickou analýzu a ani v př́padě orientace či druhu př́́davku se nelze spoléhat na jinak striktně „pohlavně“ dodržovaný pohřební ritus. Další části keramických amfor byly ve fragmentárním stavu roztroušené v prostoru vrchních patrií pohřbených mezi zbytky blíže neurčených zviŕecích kostí. Rozbor keramického materiálu ukazuje na zařazení hrobového inventáře do nálezové skupiny III, která je označovaná za lokální provenienci kultury se šn̆ůrovou keramikou (Buchvaldek 1986, 105-106). Provedené radiouhlíkové datování $\mathrm{z}$ antropologického materiálu dospělého jedince určila stáří hrobů v rozmezí let $3981 \pm 22$ BP. Získaná data korespondují s hroby III. nálezové skupiny z Vikletic (Buchvaldek - Koutecký 1970; Buchvaldek 1986, 107: hrob 119/1963: GrN-9481, $3935 \pm 35$; hrob 58/1964: GrN-9482, $3860 \pm 35$ ) nebo Vliněvsi (Dobeš Limburský a kol. 2013: obj. 3512: CRL-10178, $3971 \pm$ 134; obj. 5790: CRL-9201, $3961 \pm 99$ BP).

V západní a jihozápadní části pražského území není výskyt izolovaných hrobů kultury se šňůrovou keramikou jevem nijak zvláštním. Kromě druhého největšího pohřebiště kultury se šňůrovou keramikou s 56 hroby z jižnějších katastrů Jinonic a Stodůlek (Buchvaldek - Kovář́k 1993, 119-174; Buchvaldek Popelka 1994, 21-52; Turek 2005, 270-271, 331-332, lokalita Jinonice, 336-337, lokalita Stodůlky 3), registrujeme $\mathrm{v}$ regionu většinou ojedinělé pohřební aktivity této kultury. Pravděpodobně lze uvažovat o možnosti, že nad jednotlivými hroby byly navršeny mohyly. Mohylové násypy tak mohly obsahovat více pohřbů, které byly později zničeny rozoráním mohyl (cf. Buchvaldek - Popelka 1994, 26; Neustupný 2008, 131). V prostoru Centrálního parku ve Stodůlkách byly odkryté dva dětské pohřby s poměrně bohatou výbavou keramiky, kamennou bulavou a dvěma pazourkovými čepelkami (Zemanová - Turek 2010, 657-666). Dva hroby dospělých jedinců s chudou hrobovou výbavou pravděpodobně téže kultury na stejném katastru byly prozkoumány v Petrž́llkové ulici (Kvietok - Kuchařrik - Koštál - Horák 2009, 5-6). Z ulice K Třebonicům v Řeporyjích pochází hrob nedospělého jedince $s$ keramikou a kamen- 
nou sekerkou a čepelkou za silicitu glacigénních sedimentů (Petriščáková 2018, v tisku). Západně od ulice K Třebonicům v Jáchymovské ulici v prostoru cvičiště TJ Sokol Řepy byly nalezeny čtyři hroby kultury se šňůrovou keramikou s keramickými nádobami a jednou bilaterálně retušovanou čepelkou z baltského pazourku (Stocký 1926, 152; Buchvaldek - Havel - Kovárík 1991, 174-175; Turek 2005, 336, lokalita Řeporyje 3). Při výzkumu v Horšovské ulici byl zaznamenán hrob kultury se šňůrovou keramikou vybaven pravděpodobně až devíti keramickými nádobami, dvěma broušenými sekeromlaty, sekerkou, dvěma bulavami menších rozměrů a čtyřmi silicitovými úštěpy (Zelená 2012, 8). Poblíž polohy „Na Maňoušce“ mezi ulicemi K Závětinám a Tělovýchovná, na jižním okraji obce Řeporyje nedaleko bývalé Štěpánkové cihelny byly objeveny dva hroby ve skrčené poloze kultury se šňůrovou keramikou. Z hrobů pochází dvě amforky a dóza, které jsou uložené v NM (Neumann 1900-1901, 254; Stocký 1926, obr. 44; Buchvaldek - Havel - Kovárík 1991, 174; Turek 2005, 336, lokalita Řeporyje 1) Z neznámé polohy v Řeporyjích pravděpodobně ze dvou rozrušených hrobů jsou v Národním muzeu uložené amfora a fasetovaný sekeromlat (Stocký 1926, tab. LXXXI: 4ab; Buchvaldek - Havel - Kovář́k 1991, 175; Turek 2005, 336, lokalita Řeporyje 4). V souvislosti se zde publikovaným ruzyňským hrobem bychom mohli předpokládat, že př́padné další aktivity kultury se šňůrovou keramikou na zkoumaném území mohly být zničeny mladšími situacemi. Tuto teorii zatím nelze potvrdit, protože při předběžném zpracování výzkumu nebyly indikovány žádné jiné objekty či intruze tohoto období.

\section{Př́loha}

\section{Antropologická analýza pohřbů kultury se šňưrovou keramikou $\mathrm{z}$ Prahy-Ruzyně}

Dobisíková Miluše - Velemínský Petr

V hrobu 9 ležely kosterní pozůstatky dvou jedinců:

\section{1. jedinec}

Lebka: malé zlomky lebeční klenby s výrazným zevním týlním hrbolem.

Osozý skelet: pouze bederní páteř s př́itomnou spondylózou, zlomek kř́ížové kosti bez spondylózy a zlomky žeber bez informací.

Horní končetiny: lehce poškozené vřetenní kosti, zlomky záprstních kostí a 1 článek prstu.

Dolní končetiny: pánevní kosti s úzkým velkým sedacím zářezem, bez vytvořeného předboltcového žlábku a s boltcovitou plochou bud' vyhlazenou, nebo pokrytou uzlíky; stehenní kosti platymerické, s výraznou drsnou čárou a s náznakem třetího cho- cholíku; holenní kosti platyknemické, kolenní čéšky s patrnou entezopatií, obě patní kosti, levá kost hlezenní a lod'kovitá,

Pohlaví jsme odhadovali z morfologických znaků pánevní kosti, z rozměrů hlezenní kosti a celkové robusticity, věk byl odhadován ze stavu boltcovité kloubní plochy a celkového stavu kostí.

Příměs: zvířecí kost

délka vřetenní kosti

vpravo vlevo

délka stehenní kosti

asi 250 asi 250

transverzální průměr hlavice

stehenní kosti

$463 \quad 465$

podtrochanterický transverzální

průměr těla stehenní kosti

podtrochanterický předozadní

průměr těla stehenní kosti

index platymerie

délka holenní kosti

transverzální průměr holenní kosti

ve výši nutričního otvoru

předozadní průměr holenní kosti

ve výši nutričního otvoru

index platyknemie

délka hlezenní kosti

55

šírka hlezenní kosti
muž, maturus (40-60 let), $172 \mathrm{~cm}$, robustní, L+, $P_{++}$

\section{2. jedinec}

Kosterní pozůstatky nedospělé osoby. Zachovaly se zlomky lebeční klenby, 1 horní mléčná stolička, zlomky žeber, zlomek pažní kosti, zlomek pravé loketní kosti a snad i kosti vřetenní. Věk byl odhadován z délky stehenní kosti a přítomnosti mléčné stoličky.

délka pravé stehenní kosti

dítě, infans II (7-10 let), L+. P (++)

\section{Literatura}

Baštová, D. - Šmolíková, M. - Zavřel, J. 2011: Hromadný nález broušené industrie z mladšího neolitu v Praze-Ruzyni. Archeologie ve středních Čechách 15/1, 67-78.

Baštová, D. - Šmolíková, M. 1999: Archeologický výzkum Praha 6 - Ruzyně. Silniční okruh kolem Prahy, stavba 517 Řepy-Ruzyně. Nálezová zpráva. Uloženo v Archivu Oddělení Archeologických sbírek Muzea hlavního města Prahy, č. j. 014/2018.

Buchvaldek, M. 1986: Kultura se šňůrovou keramikou ve střední Evropě. I. Skupiny mezi Harcem a Bílými Karpaty. Praehistorica 12. Praha.

Buchvaldek, M. - Koutecký, D. 1970: Vikletice. Ein schnurkeramisches Gräberfeld. Praehistorica 3. Praha.

Buchvaldek, M. - Kovárŕḱ, f. 1993: Pohřebiště se šňůrovou keramikou v Praze-Jinonicích. Doplněk ke Katalogu šňůrové keramiky v Čechách VI. Praehistorica 20, 119-174. 
Buchvaldek, M. - Popelka, M. 1994: Poznámky k pohřebišti se šňůrovou keramikou v Praze-Jinonicích. Praehistorica 21. Varia Archaeologica 6, 21-52.

Buchvaldek, M. - Havel, f. - Kováŕ̌́k, f. 1991: Katalog šňůrové keramiky v Čechách VI. Praha. Praehistorica 17, 151-205.

Dobeš, M. - Limburský, P. 2013: Pohřebiště staršího eneolitu a šňůrové keramiky ve Vliněvsi. Archeologické studijní materiály 22 .

Dobisíková, M. - Velemínský, P. 2015: Základní antropologická charakteristika kosterních pozůstatků odkrytých v Praze 5 - Ruzyni v roce 1999. Antropologický posudek uložený v Archivu Oddělení archeologických sbírek Muzea hlavního města Prahy.

Kvietok, M. - Kuchařík, M. - Koštál, f. - Horák, f. 2009: Bytové domy Petržílková, ul. Petržílková, Praha 13 - Stodůlky, předstihový výzkum. In: M. Kvietok M. Kuchař́k - J. Koštál - J. Horák, Drobné archeologické výzkumy společnosti Labrys o. p. s. v roce 2008, Zprávy české archeologické společnosti 2008, Supplément 75, 5-6.

Neumann, E. 1900-1901: Kostrové hroby ve Stodůlkách. Památky archeologické 19, 66-67.

Neustupný, E. 2008 (ed.): Archeologie pravěkých Čech 4. Eneolit. Praha.

Petrišćáková, K. 2018: Hrob kultury se šňůrovou keramikou v Praze-Řeporyjích. Archaeologica Pragensia 24, v tisku.

Petrišćáková, K. - Pavúk, P. - Baštová, D. - Šmolíková, M. 2015: Pohrebisko staršej únětickej kultúry z Prahy-Ruzyně. Príspevok k počiatkom doby bronzovej v Čechách. Studia Hercynia 19/1-2, 25-53, 293-294.

Stocký, A. 1926: Pravěk země české. Díl I. Věk kamenný. Praha.

Turek, F. 2001: Late Eneolithic mortuary practices and thein social signifikance. https://www.academia.edu/1139460 /Late_Eneolithic_mortuary_practices_and_their _social_significance.

Turek, 7. 2005: Praha kamenná. Eneolit - pozdní doba kamenná. In: M. Lutovský - L. Smejtek a kolektiv, Pravěká Praha. Praha, 239-348.

Zemanová, P. - Turek, f. 2010: Dětské pohřby z období šňůrové keramiky z Prahy-Stodůlek. Archeologie ve středních Čechách 14/2, 657-666.

\section{Burials of the Corded Ware Culture from Prague-Ruzyně}

Two burials of Corded Ware Culture were excavated in the course of the recscue excavation by the City of Prague Museum in 1999 in the polycultural settlement in Prague-Ruzyně during the bypass construction (No. 517 Repy-Ruzyně). The isolated grave contained the adult (man, $40-60$ years) and child (7-10 years) inhumations. Both lay in a crouched position on the right side with the head orientated to West-North-West. This is typical male orientation, also the burial assemblage - amphoras - reflects mostly the male gender. Only one mug, typical for female gender, behind the child head was registered. The question is whether the child inhumation belongs to male or female gender. Analysed pottery put this grave in the find-group III (according to Buchvaldek 1986, 105-106). Radiocarbon analysis of the adult human remains determines age between the years $3981 \pm 22 \mathrm{BP}$. This data corresponds with the other graves of the find-group III from Vikletice (district Chomutov, Buchvaldek - Koutecký 1970; Buchvaldek 1986, 107: grave 119/1963: GrN-9481, $3935 \pm 35$; grave 58/1964: GrN-9482, $3860 \pm 35$ ) and Vliněves (dictrict Mělník, Dobeš - Limburský et al. 2013, 106: grave 3512: CRL-10178, $3971 \pm 134$; grave 5790: CRL-9201, $3961 \pm 99$ BP).

\section{Katarína Petriščáková}

Muzeum Hlavního města Prahy

Oddělení archeologických sbírek

Kožná 1/475

11000 Praha 1

petriscakova@muzeumprahy.cz

Miroslava Šmolíková

Muzeum Hlavního města Prahy

Oddělení archeologických sbírek

Kožná 1/475

11000 Praha 1

smolikova@muzeumprahy.cz 